to the dominance of neoliberal frameworks of sexuality, gender, and power. I might quibble that structural analysis, based on either an explicit or implicit Marxist framework, is the bedrock of queer theory; as university lecturers we are always chanting the mantra of system and structure, not individual psychology, in understanding the roots of oppression. Left-leaning social theorists have always clung to their Marxist critiques of neoliberalism even as Marxism as a viable political/economic system has faded from conversation, as Liu rightly notes. The real delight in this text is the way Liu "traces the dynamic traditions of queer art, film, literature, social movements, and popular culture in the Chinas that produce a Marxist philosophy of human sociality" (31). Liu moves queer theory out of the academy to show how a coherent philosophy based on Marxist analysis has developed in the Chinas within the broader arena of artists and activists.

Liu beautifully fleshes out these broad theoretical claims when he introduces the reader to the actual examples of Chinese Queer Theory throughout the text. For example, one of the most remarkable queer Chinese artists Liu discusses, Cui Zi'en, in his "shocking and perverse" films, relies on spontaneity "as an anticapitalist mode of creativity" (49-50). Rather than focusing on the normative gay, neoliberal, "out and proud" subject, Cui includes "transvestites, voyeurs, boy toys, creepy uncles, gay-for-pay evangelists, bi-curious straight men, money boys, incestuous relatives, MTFs ... insatiable sluts, dinosaurs, reptiles, and extra-terrestrials ... subjects who are certainly 'queer' and living at some critical distance from cultural norms and power" (49). Neoliberal identity formation, along with the obligatory “coming out story," are impossible within Cui Zi'en's work, as Liu argues. Through these stories, Liu argues that Cui's work is "a reimagination of the possibilities of human sexuality, creativity, and fulfillment under conditions of reified labor" (4950). I will leave the reader to revel in Liu's nuanced discussion of the unruly, uncontained Queer Marxism of Cui and the many other artists covered. Throughout the text, Liu convincingly argues that the Chinas must not be reduced through an Orientalist lens to a field-site for the emergence of the global queer, but rather as the source of an analytic that provides the creative and intellectual space to lay bare the workings of neoliberal power and imagining that things could be otherwise.

Megan Sinnott Georgia State University

\title{
Tim McCaskell, Queer Progress: From Homophobia to Homonationalism (Toronto: Between the Lines, 2016). 520pp. Paperback \$39.95.
}

In Queer Progress: From Homophobia to Homonationalism Tim McCaskell quite comprehensively covers 40 years of activism within the LGBTQ movement, from 1974 2014. His capturing of these times is part subjective — as a gay activist he was part of the The Body Politic collective, contributed to the work of the Right to Privacy 
Committee (RTPC), was a founder of AIDS Action Now! (AAN) and spokesperson for Queers Against Israeli Apartheid (QuAIA). This is not to mention his international activities, including being an advocate for the Simon Nkoli Anti-Apartheid Committee on behalf of gay South African anti-apartheid activist Simon Nkoli. Additionally, and to his credit, McCaskell captures numerous other developments within the LGBTQ movement that he was not directly involved in, such as censorship, same-sex benefits, policing issues, same-sex marriage, and trans concerns, among others.

What distinguishes Queer Progress from the works of other historical writings on the Canadian LGBTQ movement_-such as Barry Adam's The Rise of $A$ Gay and Lesbian Movement (1987), Gary Kinsman's Regulation of Desire (1987), Miriam Smith's Lesbian and Gay Rights in Canada (1999), David Rayside's On the Fringe (1998) and Queer Inclusions, Continental Divisions (2008), and Tom Warner's Never Going Back (2002) — is it's particular focus on Toronto. Whereas other works tend to focus on the national development of the LGBTQ movement, McCaskell demonstrates what has long been known, that in Canada Toronto has and continues to forge a unique stance on LGBTQ issues, often at the forefront of the nation, influencing the rest of the country and other nations as a result. Yet, as McCaskell argues, the development of the LGBTQ movement, both in Toronto and in general, and the stances it has taken have not always been necessarily progressive. Hence his choice of title, which references the "queer" trajectory of the LGBTQ movement in Toronto, which went from seeking societal change in the early years of the gay liberation movement to acceptance and respectability via assimilation today. This transformation leaves many of us questioning such "progress."

McCaskell argues that the broad LGBTQ movement proceeded along this queer trajectory because it lost sight of class issues that heavily influenced the early gay liberation movement through Marxist thought and failed to pay close enough attention to issues concerning race, the latter particularly in Toronto. Although he gives extensive attention to internalized sexism and how lesbians and bisexual women felt sidelined by gay men, a major factor in gay liberation's implosion, he ultimately concludes that the issues of gay men and lesbians are inherently different. His larger criticisms are reserved for class and race, and how both are embedded in the diverse LGBTQ movement, yet not adequately addressed. What needs to be noted here is that McCaskell, as a Caucasian man, had developed an interest in international issues from early on when he covered such news for The Body Politic. This led to international travel and involvement in international advocacy issues such as those of South African anti-apartheid and Israel's treatment of queer Palestinians. His long-term relationship with Trinidadian artist Richard Fung had him moving in racially diverse social circles, which often intersected with class differences. This was not necessarily the case with other active members of the LGBTQ movement, which was predominantly led by middle class, white, gay men.

The issues of race and class, separately and intersectionally, were overlaid 
with the larger political contexts of the times which the modern day LGBTQ movement found itself within. From the social conservatism that gay liberationists initially fought against to the insidious influence of current day neoliberalism, McCaskell uses extensive examples to effectively demonstrate how focus shifted from a liberationist perspective of social change that would free up everyone's sexuality regardless of orientation to an individualized focus on attaining rights equal to the privileged (read heterosexuals). Using this nuanced approach McCaskell offers a critical analysis that is both macro regarding the socio-political shifts of society (industrialized nations in particular such as Canada, the UK and the US) and micro regarding how personalities and agendas within the LGBTQ movement transpired and, in many cases, unravelled.

McCaskell provides a clear and accessible understanding of social conservatism, liberalism, moves away from Keynesianism and towards neoliberalism, as well as a fairly vast and comprehensive breadth of issues faced and taken up by the broad LGBTQ movement over the 40-year scope of the book. Nevertheless, I felt there were a number of occasions the book fell short on depth regarding the internal struggles of the movement at a micro level. For example, McCaskell's critique of the professionalization of AIDS service organisations (ASOs) did not extend to how this dynamic similarly transpired with other LGBTQ organisations within the LGBTQ movement. Prime examples of such professionalization are Egale nationally and The 519 locally in Toronto, and the empire-building aspect of such institutionalisation, as demonstrated by both these organisations. This critique is more attributed to the challenges of subjectively undertaking historical research in which one is unevenly involved than of McCaskell's efforts.

A substantial 473 pages, Queer Progress consists of a mostly chronological series of vignettes that sometimes flow seamlessly together, but often times not (McCaskell's tendency to close each vignette with cliff-hangers, especially earlier in the book, is unnecessary given the already interesting content). Still, the vignettes reveal the barrage of issues, which activists such as McCaskell must contend with, either directly or indirectly, as such issues have an impact on the LGBTQ movement as a whole. Also within the vast array of issues McCaskell weaves through are small yet important personal nuggets of how he himself was impacted. Most touchingly was how he, diagnosed with HIV early on in the AIDS crisis, courageously and with fortitude continued his activist work, while witnessing numerous fellow activists cut down in their prime.

Queer Progress: From Homophobia to Homonationalism not only provides an important historical account of LGBTQ activism in Toronto and its contribution to the broader national and international LGBTQ movement, but society at large. Further, it examines the trajectories of change socio-politically, economically, and psychically regarding the place of sexuality, gender, gender identity and expression, race, and class within that movement. McCaskell does not purport to have answers as to how today's queer movement should proceed, but provides relevant insight to 
consider, particularly around homonationalism. This is an important contribution to our social and historical understanding of LGBTQ issues, how these issues have been taken up by the movement, and their implications on LGBTQ people and society in general.

Nick J. Mulé

York University

\section{Joanna Bellis and Laura Slater, eds., Representing War and Violence, 1250-1600 (Woodbridge: Boydell Press, 2016). 232pp. Hardcover $\$ 90.00$}

In the last twenty years, medieval violence has garnered a great deal of critical attention: war, torture, punishment, and personal violence have been the subject of numerous studies. Representing War and Violence $1250-1600$ is a valuable new addition to the growing body of scholarship on medieval violence that focuses an interdisciplinary lens on the ambivalence and nuance of depicting and responding to warfare.

Grounded in the research of Richard Kaeuper, who provides the first essay, Representing War offers innovative research on specific aspects of warfare in literature, art, autobiography, and historiography. While the introduction makes assertive claims to being the first such collection, its arguments are part of a much larger interdisciplinary push in medieval studies. The innovation here is the dialogue among disciplines and the specific contribution each article makes to the field. The volume covers mostly France and England within a 350-year period, which is certainly not exhaustive, but does not pretend to be. The editors acknowledge the limitations of the collection while providing a comprehensive framework for analysing and engaging with interdisciplinary sources. One of the shortcomings of medieval studies is the tendency of research to micro-focus on singular geographical locations, languages, or disciplines. Representing War goes a long way in redressing that shortcoming regarding medieval attitudes towards violence.

In the introduction, Bellis and Slater argue that much previous work on medieval violence and warfare looked at either representation or aesthetics, but rarely considered both together. Their aim is to offer a new perspective on the social, artistic, and aesthetic treatment of violence, its representations and imagination, a goal that they largely achieve through the lenses - ethical, argumentative, and spiritual - they apply in their analysis of how war and violence were scrutinized by medieval audiences. The editors recognize the pitfalls in interpreting audience response and in separating modern attitudes towards war and violence from medieval sources. It would, however, strengthen their argument if they did not consistently put terminology in quotation marks, as though they are not wholly convinced by their vocabulary or that of other critics. At times, the introduction seems to chide the mass of medievalists for imposing modern sensibilities upon medieval texts, which cer- 